\title{
A Scottish Art and Heart: The Transparent Influence of the Scottish School of Art on Erskine Nicol's Depictions of Ireland
}

Peinture et parenté écossaises : l'influence transparente de l'école écossaise sur les tableaux irlandais d'Erskine Nicol

\section{Amélie Dochy}

\section{OpenEdition \\ Journals}

\section{Electronic version}

URL: http://journals.openedition.org/etudesecossaises/837

DOI: $10.4000 /$ etudesecossaises.837

ISSN: 1969-6337

\section{Publisher}

UGA Éditions/Université Grenoble Alpes

\section{Printed version}

Date of publication: 15 April 2013

Number of pages: $119-140$

ISBN: 978-2-84310-246-2

ISSN: $1240-1439$

\section{Electronic reference}

Amélie Dochy, "A Scottish Art and Heart: The Transparent Influence of the Scottish School of Art on Erskine Nicol's Depictions of Ireland", Études écossaises [Online], 16 | 2013, Online since 15 April 2014 connection on 15 March 2021. URL: http://journals.openedition.org/etudesecossaises/837 ; DOI: https://doi.org/10.4000/etudesecossaises.837 


\title{
A Scottish Art and Heart: The Transparent Influence of the Scottish School of Art on Erskine Nicol's Depictions of Ireland
}

\author{
"The Arts, unlike the exact sciences, are coloured by \\ the temperaments, beliefs, and outward environment \\ of the peoples amongst whom they flourish." \\ William D. McKay, The Scottish School of Painting, 1906, p. 3.
}

Erskine Nicol (3 July 1825-8 March 1904) was a Scottish painter who lived in Dublin between 1845 and 1850. When he went back to Scotland, his paintings attracted the attention of the British public for their fine quality, lively colours and the scenes taken from everyday life, so that by the 1850s, Nicol was already famous and was celebrated by art critics as the painter of Ireland. ${ }^{1}$ He then moved to London in 1863, joined the

1. Nicol was considered the painter of Ireland because most of his representations of the Irish were successful not only among the middle and upper-middle classes, who could go and see them regularly in the galleries in London or Edinburgh, but also among the working classes. A contemporary art historian described the "eagerness to possess engravings from [Nicol's] pictures which is shown by the same class of collectors who, not in a position to acquire the pictures themselves, gather together and highly prize the replicas in black and white of the works of such masters as Wilkie and Webster. What these latter have done in the way of portraying the homely, familiar, every-day side of British life, Mr. Nicol does for the Irish" (Meynell, 1883, p. 150). Indeed, Nicol was often complimented for being the "unrivalled" delineator of Irish life (The Caledonian Mercury, 4 March 1858). Given the success, as well as the number of his representations of Ireland, an art critic even claimed in 1870 that Nicol should have been Irish: "His art is so thoroughly identified with the land of the shamrock that one might naturally suppose him, not only to have been born there, but also to have passed his whole life among its people." (Dafforne, The Art Fournal, 1 March 1870, p. 65.) A few months later, an anonymous article published in the same magazine read: "There is no chance of mistaking a picture by Mr. Nicol for a work by any other painter of the more humble classes of Irish, be they dwellers in town or country, whom, under certain humorous conditions, almost inseparable from their nationality, he seems entirely to monopolise: no other artist must attempt to rival him on his own ground with any probability of success." (The Art fournal, 1 July 1871, p. 180) 
Royal Academy in 1866, and had exhibitions in a variety of places in the capital (notably at the Crystal Palace), in Birmingham, Leeds, Edinburgh, as well as in numerous private galleries. Yet his vision of Ireland was not entirely new or original, as Scottish painters such as David Wilkie (1785-1841), had focused on the island before. The latter is considered one of the major painters of the Scottish school, composed of a group of nineteenth-century artists characterised by their common themes and similar styles. To what extent did this school influence the work of Erskine Nicol? How could a painter of Irish life be considered a member of a Scottish school of art? The link between the artistic current and Nicol's source of inspiration is indeed transparent. Several elements can easily be identified as being typically Scottish. However, other characteristics of his work, such as its lack of "Highlandism", or representations of an imagery which was deemed traditionally Scottish, differentiate his paintings from those of that school. Nonetheless, Nicol's lack of interest in "Highlandism" did not mean that he was not interested in the contemporary life of his fellow countrymen, and his artworks reflect the reality of Scottish life during his lifetime.

From the middle of the nineteenth century onwards, art critics began to speak of "the Scottish school", as noted by David and Francina Irwin, who claim:

This was primarily a question of subject-matter rather than of style. The popularity of subjects connected with the life, landscape, and history of Scotland was largely due to the widespread appreciation of Sir Walter Scott's novels, and was soon to be reinforced by Queen Victoria's annual residence at Balmoral and her genuine love for her northern kingdom. (Irwin, 1975, p. 283)

Painters in Scotland were encouraged to represent Scottish subjects, thanks to the commissions offered by several patrons - commissions which became all the more important as the middle of the century was characterised by economic prosperity in Scotland. Moreover, Scottish painters benefited from the support of newly-created institutions, such as The Royal Scottish Academy, which received its royal charter in 1838, or the Association for the Promotion of the Fine Arts in Scotland, dating back to 1833 . The latter used the yearly registration fees paid by its members to buy original works of art and to reproduce them in the form of engravings, later distributed to all its subscribers. This allowed a greater circulation of Scottish works of art, and improved their visibility on the British art market. Finally, young artists in Scotland were given a chance to receive artistic training at the Trustees' Academy, a school of design which had been merged, in 1800, with John Graham's Academy, which 
was itself devoted to the study of the fine arts. The Trustees' Academy was the only school which provided an artistic training in Scotland, and David Wilkie (1785-1841) - "one of the founders of Scots art", whose "genius and influence" gave impetus to the works of his fellow artistswas one of the students who attended the classes of John Graham in 1804 (Pinnington, 1900, pp. 13-4).

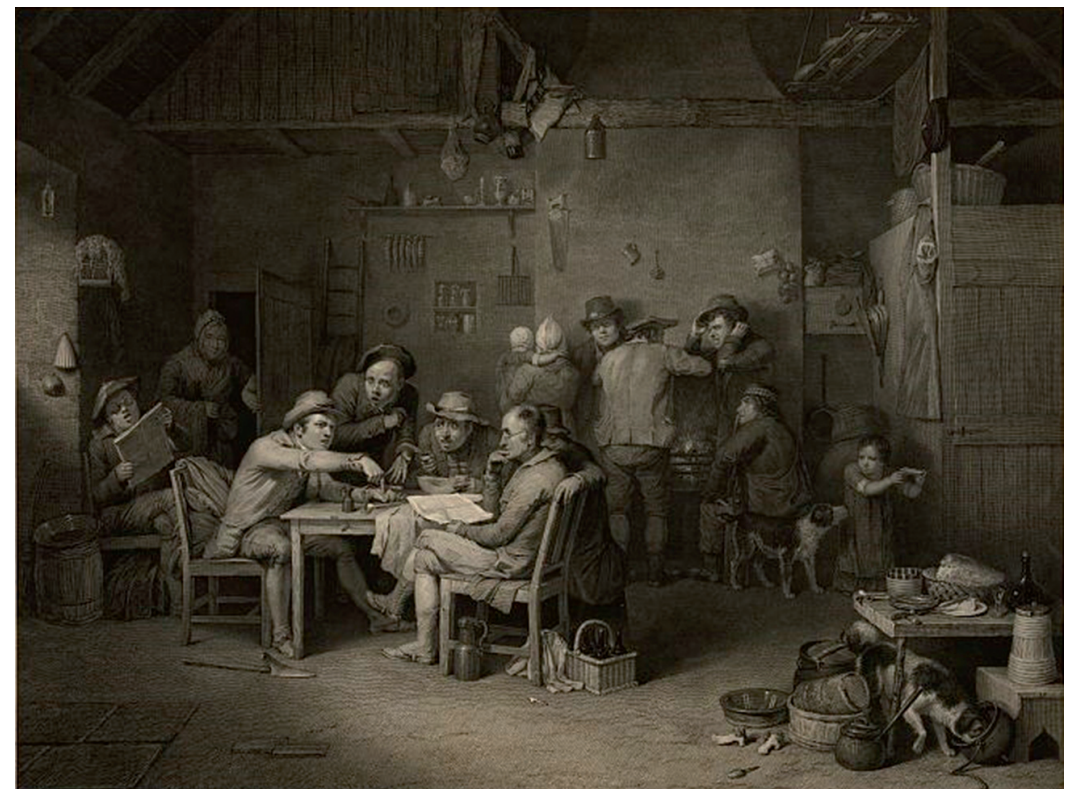

David Wilkie, Village Politicians, 1806, private collection; reproduced here in the form of an engraving by Raimbach, 1813.

Public domain (<www.wikipaintings.org/en/david-wilkie/village-politicians $>$ ).

In paintings like Pitlessie Fair (1804), or Village Politicians (1806), which made Wilkie famous, the viewer can see a depiction of rural life - a theme inherited from the Scottish artist David Allan (1744-1796). Wilkie's reputation in London was established by these early canvasses, remarked for their humour.

These pictures reveal a "fondness for anecdote and for fine nuances of expression" (Irwin, 1975, p. 189) as well as the influence of the Dutch school of painting in the composition. Village Politicians was inspired by Hector Macneil's poem "Will and Jean", and shows the encounter of the two main characters at the ale-house (Pinnington, p. 32, pp. 46-52). The grouping of the main figures in the left-hand side of the picture, and the presence of farcical details, such as a hungry dog rummaging through the 
pots in the lower right corner, reveal the influence of the Netherlandish school on Wilkie's art. Besides, it is well known that when he painted The Blind Fiddler for Sir George Beaumont in 1806, it was "with a Teniers beside him, lent by his liberal friend and patron" (McKay, 1906, p. 71). The picture, which was then directly inspired by a Dutch painting, can now be seen on the website of the Tate Gallery. ${ }^{2}$ Although Wilkie died in 1841, when Erskine Nicol was only sixteen years old, the young artist doubtlessly knew his work. Indeed, Nicol also attended the Trustees' Academy, and it was precisely in 1841 that he sent his first work of art to the Royal Scottish Academy, a still-life entitled Fruit (Rinder, 1917, p. 284).

Interestingly, Nicol's favourite subjects seem to derive from Wilkie's: the focus on domestic life, or on the customs and characters of the rural population, are parts of the legacy of this artist. Nicol did not choose to represent the aristocracy but the common folk, and those who belonged to lower social classes in general. Furthermore, his Irish subjects are treated in a manner which is redolent of Wilkie's style. In 1856, Nicol painted The Ryans and the Dwyers, Calumniated Men, an oil on canvas which was both exhibited at the Royal Academy in London (1857), and at the Royal Scottish Academy in Edinburgh (1858), where it was well received by English and Scottish art critics alike. They praised the nicely delineated physiognomy of the characters, as well as their expressions, ${ }^{3}$ but none of them seems to have noticed the resemblance with Wilkie's Village Politicians. However, despite the change of scale, many similarities can be noted. As far as the theme is concerned, both paintings represent an indoor scene, set in a public house, where a customer reads a newspaper to a few others, which was a new phenomenon in the 19th century, according to Tri Tran. ${ }^{4}$ Wilkie studied this contemporary habit several times in his career, especially with his famous Chelsea Pensioners (1822, Apsley House, The Wellington Museum, London), but also with Reading the Newes (1820, Laing Art Gallery, Newcastle) or Newesmongers (1821, Tate, London). In the Village Politicians, as well as in The Ryans and the Dwyers, the familiar furniture and crockery of a tavern are carefully detailed: in Wilkie's painting, there are pots in the background, hanging from the beam above the characters, or standing on a shelf, just above a few herrings and a grill. In Nicol's, a pewter beer jug occupies the centre of the frame, with a stoneware whiskey jug to its left, and another one hanging

2. The picture was presented at the Tate Gallery by Beaumont himself in 1826, and it can now be seen at the following address: <www.tate.org.uk/art/artworks/wilkie-the-blind-fiddler-n00099>.

3. The Art Fournal, 1 March 1870, p. 66; The Caledonian Mercury, 4 March 1858.

4. Private conversation, 11 May 2012. 
from the wall, next to a tea pot on a shelf, in the upper right corner. A white tablecloth, or perhaps a long napkin, spread over the table, is common to the two works, and acts as a foil for the newspaper which is being read, or has just been read, by the character who wears glasses - in each painting, the wearing of spectacles seems to underline that these sitters are literate, which might not be the case of all the other characters, considering the wide-open eyes of Wilkie's figures sitting behind the table, or the upward gaze of the peasant on the left of Nicol's picture.

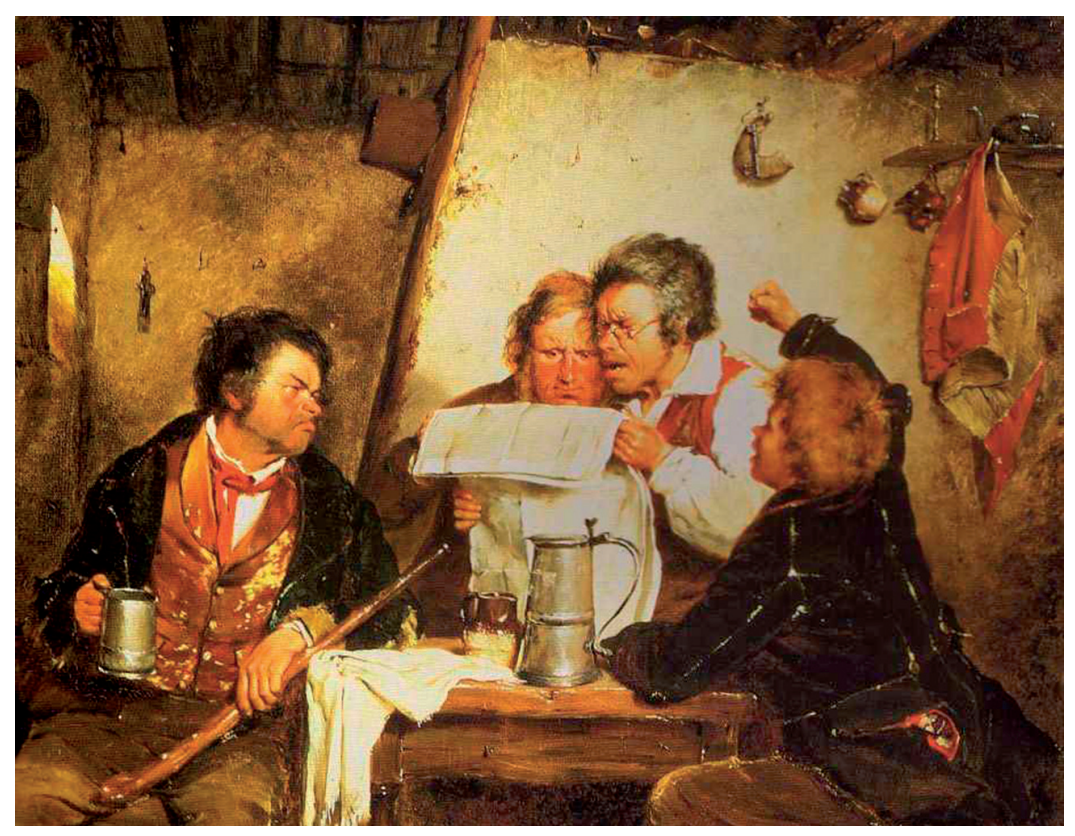

\section{Erskine Nicol, The Ryans and Dwyers, Calumniated Men, oil on canvas, $33 \times 43.5 \mathrm{~cm}, 1856$, private collection.}

(c) Christie's Images Limited (1992). ${ }^{5}$

As the latter looks at the reader instead of the newspaper, it could be imagined that he cannot read, and is therefore dependent on others to learn the news. Contrary to the red-haired man placed by Nicol against the wall, he does not try to peruse the article which is the source of his disgust. The expression, so clearly represented by the frowning eyebrows and grimacing mouth, implies that the man is heated by argument, and

5. I would like to thank Rosie Henniker-Major, of Christie's in London, for her help in getting a beautiful photograph of the painting. 
possibly by drink. This can also be said of the peasant with his arm raised and his fist clenched, whose profile seems to suggest the face of a teenager. This character and his meaningful gesture can be compared to Wilkie's outraged man, whose emphatic movement may hint at his drunkenness, as well as his anger.

Beyond the shared setting and expressions of surprise, resentment and indignation, the canvasses present a similar structure. Notwithstanding the minor characters and incidents introduced by Wilkie behind the main group, ${ }^{6}$ Nicol has used a similar triangular composition. This is even more obvious if Wilkie's painting is reversed, and if we focus on the main group, as in the image below.

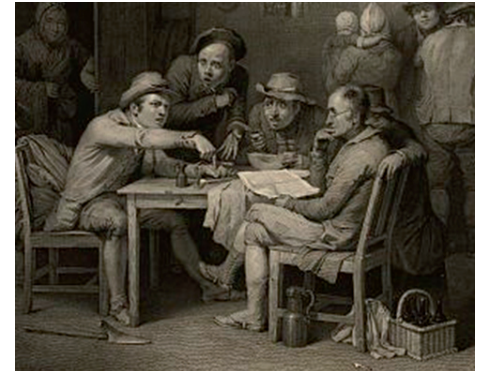

Detail from Raimbach's engraving, reproducing Wilkie's Village Politicians.

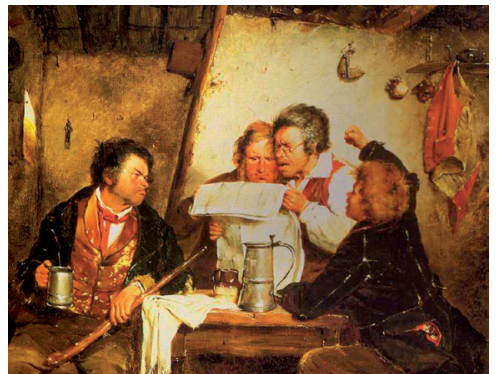

Erskine Nicol, Calumniated Men.

In both paintings the pyramidal composition is noticeable: a figure standing, taller than the others, forms the top of each triangle, while his folded arm draws a parallel with the gesture of indignation of the most irate characters. In Wilkie's painting, there is a character sitting near the standing figure, thus acting as a foil to the man who is standing, just as Nicol's reader is depicted as taller than the character placed at his left. Thus, both standing figures are enhanced, and the dark hat of Wilkie's character has turned into a mass of grey hair in Nicol's painting. The light is similar, too: light falls on the centre of the frame, so that our eyes are attracted by the whiteness of the newspaper, the focus of the viewer's attention. These similarities reveal the relationship between the two

6. From left to right, there are a man reading another newspaper aloud - as is suggested by his open mouth - , a lady coming in by the door, another one carrying a baby, a quarrel involving a party of four - one of whom is wearing a Tam O'Shanter, the traditional Scottish bonnet - and finally a child, trying to save his meal from a hungry dog, while another is licking a pot in the lower right corner. 
paintings, and that both painters were members of the Scottish school. This is why William McKay writes:

It may be that Erskine Nicol's interpretations deal with the surface of Irish life, that they embody only its humorous and picturesque aspects; they pretend to no more, but within their sphere, both as character-studies, and from a technical point of view, they give the painter a unique place in the Scottish school. (McKay, 1906, p. 347)

Therefore, Nicol's predilection for genre painting, as well as the Dutch influence marking his style, can be traced back to David Wilkie. Because of his importance on the British art market in the first decade of the nineteenth century, Wilkie defined narrative painting _ or "images that told stories" (Thomas, 2004, p. 4) — as a main feature of the Scottish school. The works of other Scottish artists of the same generation as Nicol could be quoted as further illustrations of cottage life, such as Fooling Around (undated), by Robert Gavin (1827-1883), Faults on Both Sides (1861), ${ }^{7}$ by Thomas Faed (1826-1900), or Reading by the Fireside and The Legend (1864-1878), ${ }^{8}$ painted by George Paul Chalmers (1833-1878). All these pictures illustrate the daily life of peasants taking care of their children, in the grip of connubial dispute, or relaxing as they read and tell stories by the fireside. These humorous subjects, depicting the joys and sorrows of the lower classes, were appreciated in England, where many Scottish artists had immigrated in order to sell their work. On the other hand, when Scottish artists needed to portray their wealthy fellow countrymen, the style had to be different, and this focus on everyday life in the countryside is only one of the characteristics of the Scottish school of art.

In his book Painting the Nation, John Morrison declares that between 1800 and 1920, Scottish painting could be recognised through its "unionist-nationalism", that is to say "a national identity held within the larger structure of the British Empire and supportive of it" (Morrison, 2003, p. 8). For him, Scottish painting was the expression of a national identity which did not challenge the Union with England until the beginning of the twentieth century. Throughout this period, the nationalism of Scottish painters could be witnessed in their representations of the land, the people, the history, the church, and the myths of Scotland. These myths are then identified by the author, and his remarks can be grouped

7. The picture is at the Tate, and can be seen at the address: <www.tate.org.uk/art/artworks/ faed-faults-on-both-sides-n01526>.

8. These pictures can respectively be seen at: <www.bridgemanart.com/search?filter_text $=$ reading +by+the+fireside +chalmers $\& x=0 \& y=0>$ and $<w w w$.nationalgalleries.org $/$ collection $/$ themes-inscottish-art/legend-fantasy-and-imagination/6568>. 


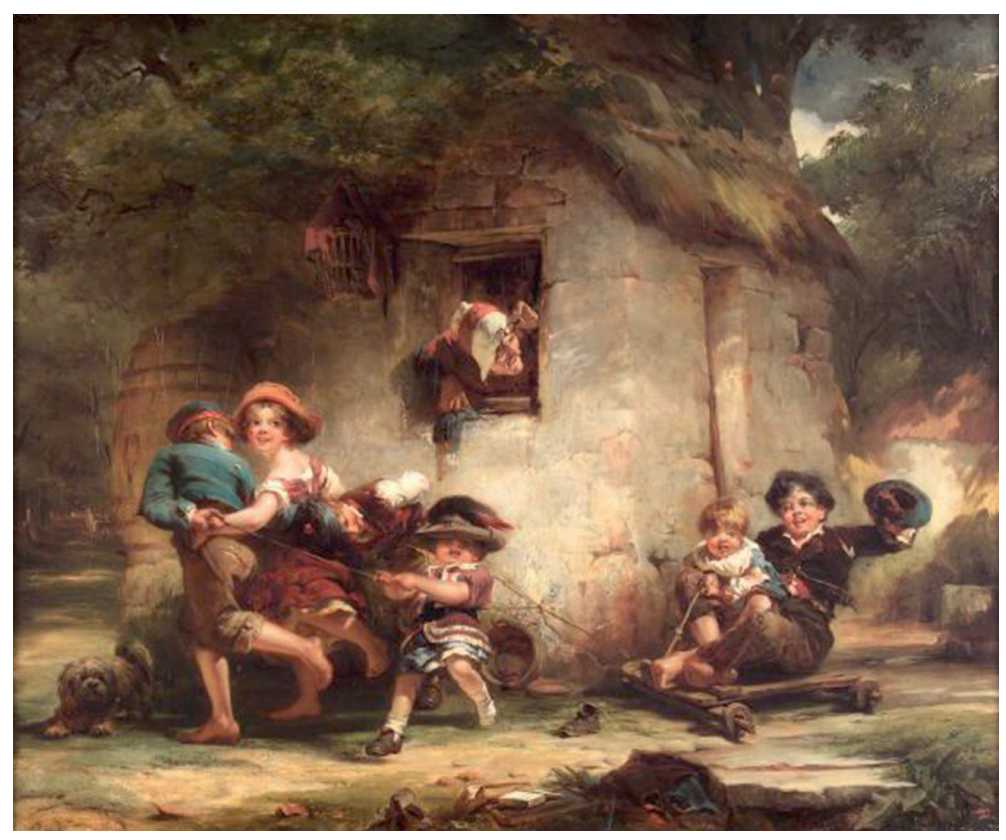

\section{Robert Gavin, Fooling Around, oil on canvas, $63 \times 75 \mathrm{~cm}$, undated, private collection. \\ (c) Courtesy of Lyon and Turnbull, all rights reserved. ${ }^{9}$}

into four categories. First, there is the belief in the "egalitarianism of the Scots" and "their lack of racism". Second is the possibility of "selfadvancement through education", which is the cause of the third principle: the "openness" and "social mobility" of Scottish society. Last but not least is the "communality of the Highlands under the clan system" (Morrison, 2003, pp. 10-12).

The association of Scottish identity with the remote people and desolate landscape of the Highlands prevailed in the nineteenth century, and this phenomenon, called "Highlandism" by Morrison, was largely fuelled by Walter Scott's writings. In his texts, the Highlands are praised as "the home of a different culture" (Morrison, 2003, p. 11), inhabited by oldfashioned individuals who are full of courage, nobility, and loyalty. Their distinct character is marked by their traditional clothes made of tartan, including a kilt, a sporran and ghillie brogues — shoes with long laces. This

9. I would like to thank Matthew McKenzie, of Lyon and Turnbull in Edinburgh, for his help in finding a beautiful photograph of this work, and for his permission to reproduce it. 
vision of Highlanders was already a fantasy in the nineteenth century, as people did not dress in this way, but it was kept alive by Walter Scott, especially when he organised the festivities for King George IV's visit to Edinburgh in $1822 .{ }^{10}$ For the occasion, all the noblemen were required to wear this so-called traditional costume, and Morrison describes the furore created by the demand for tartans, since all middle and upperclass households did not have the appropriate garments for the visit, and needed to have them prepared on time. The King himself dressed like a Highlander in order to honour his hosts, as is remembered in Wilkie's portrait of the monarch (Morrison, 2003, pp. 48-54).

"Highlandism" was a distinct feature in the art of Henry Raeburn, considered the second founding father of the Scottish school. William McKay states that "there was no school of painting [in Scotland] till Raeburn and Wilkie gave it the characteristics which endure to this day" (McKay, 1906, p. 347). Raeburn (1756-1823) was a portrait painter who was twenty-nine years older than Wilkie. Some of his portraits, such as Alastair Ranaldson Macdonell of Glengarry (1812) ${ }^{11}$ or Francis MacNab (1813), are usually given as illustrations of Highlandism.

In both paintings, the sitters wear the full paraphernalia of the Scottish clan chief. In the second, a tormented landscape is visible behind the sitter, reminding the viewer of the hardships of Highland life, and underlining the natural link between a country and its inhabitants. This romantic vision helped to define Scottish identity, and to assert how different it was from that of the English. Such a definition assimilated the whole Scottish nation to the Highlands, and the "synecdoche Highlands/ Scotland", to repeat Marion Amblard's phrase (Amblard, 2009, p. 197), was oblivious of the Lowlands, Scotland's second other main geographical region which was already industrialized by the middle of the nineteenth century. Nevertheless, Scotland was commonly presented as a rural area, full of wild landscapes, in which peasants lived according to long-established traditions, since modern industry had not upset their old-fashioned society, organised around ancestral clans (Amblard, 2009, p. 148).

Similarly, Scottish landscape painters enhanced the magnificent beauty of the Highlands, depicted as a remote, lonely and cold setting. For instance, Glencoe (1864), which is Horatio MacCulloch's masterpiece

10. John Prebble gave an account of the visit in his book entitled The King's Faunt, Edinburgh, Birlinn, 1988.

11. The portrait of Alastair Ranaldson Macdonell of Glengarry by Raeburn is in the National Galleries of Scotland, and can be seen at the address: <www.nationalgalleries.org/collection/artistsa-z/R/4399/artist_name/Sir Henry Raeburn/record_id/2581>. 


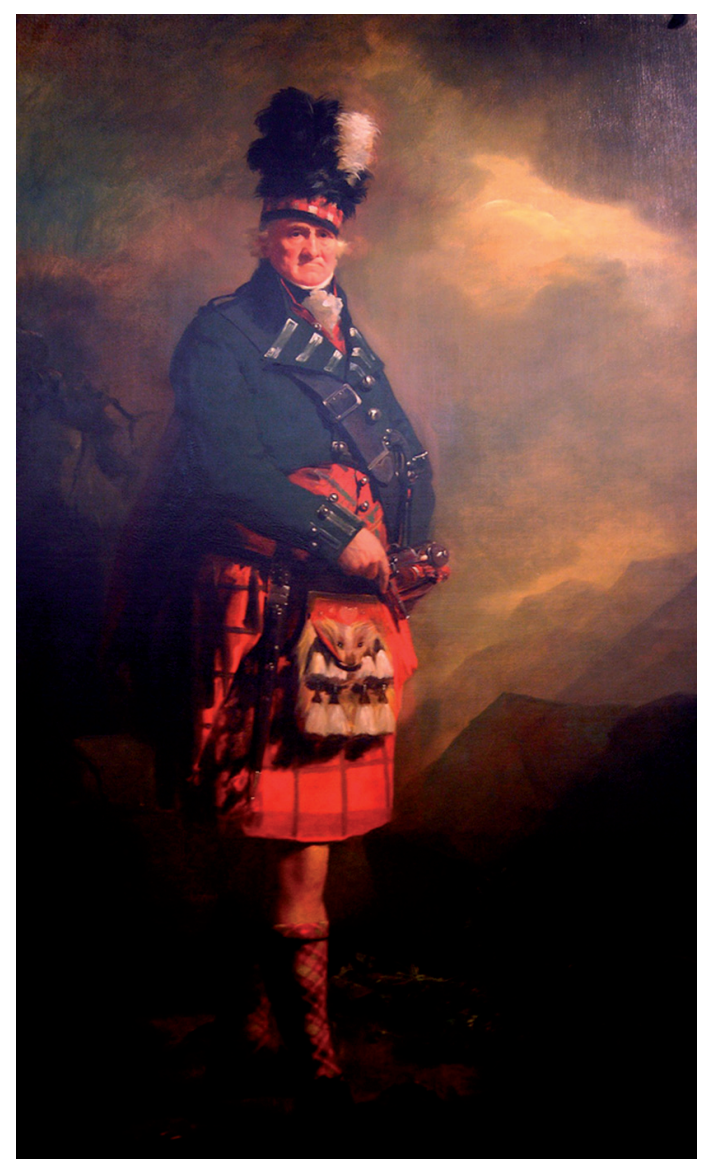

\section{Henry Raeburn, Francis MacNab, oil on canvas, 241 X 152 cm, C. 1813, Kelvingrove Art Gallery and Museum, Glasgow.}

c) Michaël Martin, all rights reserved.

(1805-1867), is selected by Morrison as the pictorial embodiment of "Highlandism" in landscape painting (Morrison, 2003, pp. 107-10). The splendour of the Scottish scenery is here illustrated by the three deer standing with majesty among the dark rocks in the foreground. One of them is directly looking at the viewer, a look which draws us to the landscape. In the background, the oil on canvas shows a rocky mountain with storm clouds above, and the rain-washed path which can be seen in the distance, on the right-hand side, opens up the perspective. But the absence of any human figure on this track, as well as the cold colours of the canvas - painted in shades of grey, blue and brown - , convey a 
feeling of desolation, sadness and death. Beyond this barren landscape lies a notorious episode of Scottish history, as is indicated by the title. As a matter of fact, the name Glencoe is sadly famous as the place where Campbell clansmen massacred their opponents, the Macdonalds of Glencoe, in February 1692. ${ }^{12}$

This historical dimension is absent from Nicol's works, in which stark landscapes or allusions to Scottish traditional dress are seldom found. Yet, it must be said that he paid particular attention to the clothes and hats really worn by peasants during his lifetime, such as the white headdress, circled with a wide dark ribbon, which was worn by Scottish women at that time and which can be observed in Grandmother and Grandson (c. 1870). In Nicol's paintings, this headdress regularly appears from one canvas to another, and is always depicted with meticulous care. That such a hat used to be a common accessory for Scottish peasant women is demonstrated by its presence in the pictures of other painters, as in Gavin's Fooling Around, in which the old woman, popping her head through the window, also wears this typical headgear. But the clothes and accessories depicted by Nicol were not part of the national folklore and as such, they were not considered as traditional. They were part of Scottish peasant life, and although they helped contemporary viewers to identify the nationality of his characters, they were not regarded as symbols of Scottishness, contrary to the elements of dress shown in Raeburn's works. The latter depicted his sitters in clothes which were seen as traditional and typical, because they were deemed representative of a Scottish past, and of the long-established lifestyle of clan chiefs, and in particular in the Highlands, the dwelling place of the leaders of the Jacobite risings, which took place in the first half of the 18th century.

Contrary to other Scottish artists including David Wilkie, William Allan (1782-1850) or James Drummond (1816-1877), Nicol did not represent key episodes of Scottish history, such as the life and death of Mary, Queen of Scots, or the debates around religious dissent and the Covenanters in the seventeenth century. This absence could be explained by Nicol's interest in Irish - rather than Scottish — subjects between the 1850 s and the 1870 s, and by the growing criticism of "Highlandism" in the 1860s. For instance, in 1868, Veri Vindex — which was the pen name of the art collector John Forbes White-- published an essay describing the inclination for historical art "given by the writings of Sir Walter Scott" as "fruitless", and calling for more realism in Scottish art (Vindex, 1868, p. 25). In this essay, the author includes the name of Nicol among

12. The oil on canvas is part of the collection of the Kelvingrove Art Gallery in Glasgow, and can be seen on their website: <http://collections.glasgowmuseums.com/starobject.html?oid=1132>. 


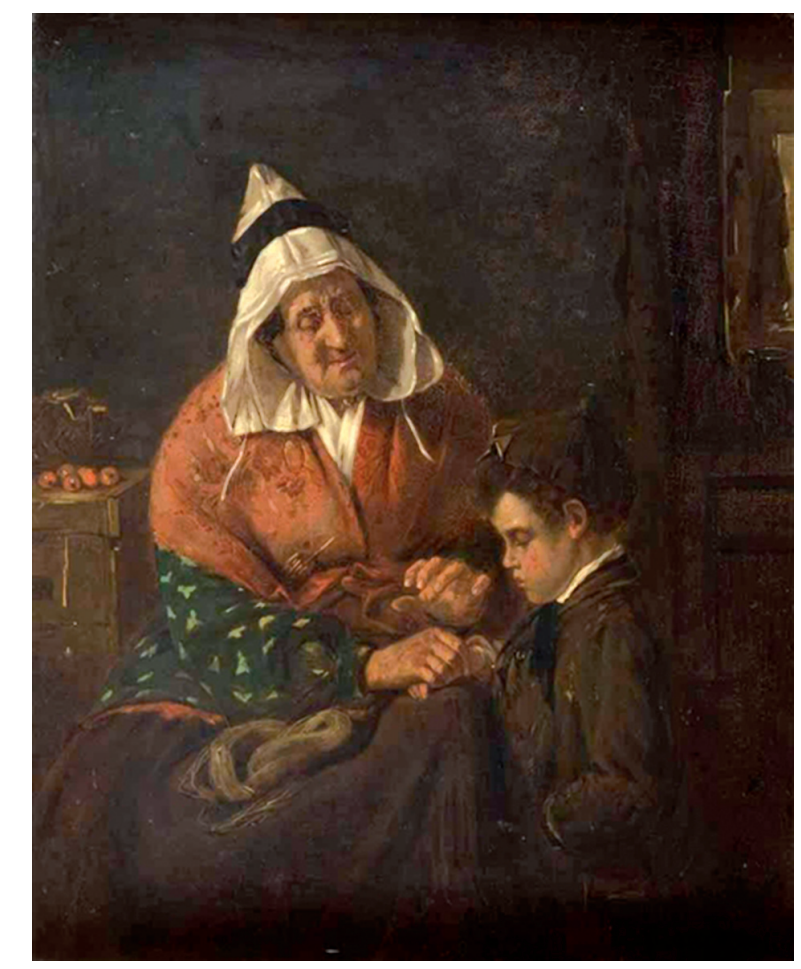

Erskine Nicol, Grandmother and Grandson, oil on canvas, $60.5 \times 50.5 \mathrm{~cm}$, c. 1875-6, private collection.

(c) Courtesy of Ross, all rights reserved. ${ }^{13}$

the nation's best painters, but not without insisting on the painter's speciality: "the unmistakenly humorous impersonation of the Irish peasant" (Vindex, 1868, p. 66, pp. 80-1).

Nevertheless, from the 1870s onwards, as he came back to Scotland and settled there, Nicol chose to represent his fellow countrymen, but in a manner which does not belong to historical genre painting. Indeed, in these paintings, his style was not much different from that of his Irish subject matters painted in the 1860 s, because in order to portray the Scots, Nicol resorted to his customary anecdotal and humorous scenes, as is the case in his undated canvas, Grandmother and Grandson (oil on canvas, 60.5 x $50.5 \mathrm{~cm}$, c. 1875-6, private collection). The grandmother - whose headdress has already been mentioned as a signal of her Scottishness-,

13. I would like to thank Daniel Clark, of Ross's, Belfast, for allowing me to use this photograph of the work. 
is comforting her grandson, whose downwards look evokes regret and sorrow. The grandmother has put her distaff under her arm, and the flax that she was spinning is laid on her lap. Her work has been interrupted by the entrance of her despondent grandson, whose hand she takes into hers, in a gesture of affection and sympathy. In 1876, the work was reproduced in the form of a black and white engraving entitled Always Tell the Truth ${ }^{14}$ so the painting probably dates back to the 1875 or 1876 .

The title provides the contemporary interpretation of the painting, which was regarded as a moralising anecdote, in which a grandmother teaches her grandson not to lie. The inclusion of moral values in genre paintings was particularly appreciated by the Victorians, and indeed, the picture must have been very popular, because it was reproduced again in 1911, this time as a coloured illustration entitled Never Tell a Lie, Duncan. The illustration was published in a book by William Harvey, Scottish Life and Character (Harvey, 1911, p. 440), and the new title attributed to Nicol's composition is significant since it refers to morality ("Never tell a lie") and also to Scottishness, with the addition of a typically Scottish first name, "Duncan", which identifies the young boy. Moreover, the title of the book announces its content: the reader will discover a definition of Scottishness, which will be both textual and visual, as the text tells anecdotes of Scottish life, whereas the images, such as those by Nicol, illustrate these stories. The choice of Nicol's picture to adorn a book on Scottish character implies that this painting was regarded as a reflection of Scottish identity until the beginning of the twentieth century.

This painting shows that the Victorian public was fond of artworks which were deemed Scottish, and were at the same time anecdotal or sentimental. Here, the nicely delineated expressions of both characters demonstrate that, whether painting Irish or Scottish scenes, Nicol preferred to paint images that told stories of everyday life rather than important episodes of Scottish history.

However, the choice of narrative painting did not mean that Nicol never alluded to contemporary issues, which are perceived as historical today. Although he did not represent events taken from a distant past, Nicol sometimes offered a glimpse of the political questions of his time. When he depicted the predicaments of Irish tenants in The Lease Refused (1863) or An Ejected Family (1853), ${ }^{15}$ he gave the viewers a reminder of the vulnerability of small Irish farmers, who could be deprived of their land and

14. It was engraved by William Henry Simmons and published in London and Washington DC by Lefèvre and Schaus respectively.

15. The 1853 oil on canvas called An Ejected Family has been in the collection of the National Gallery of Ireland, Dublin, since 1992, and a picture of it was published on their website, at the following address: < http://onlinecollection.nationalgallery.ie/view/objects/asitem/search\$0040/0/ sortNumber-asc?t:state:flow $=$ de49ce69-87ef-440e-b52a-2bdce5550be4>. 
means of subsistence if their landlords refused to renew their lease. The Lease Refused is known today thanks to its coloured reproduction published in Anna Maria Carter Hall's collection of short stories entitled Tales of Irish Life and Character. The landlord is here represented by a resigned redhaired agent who purses his lips, and whose silence implies that he cannot help the tenant. Sometimes, the tenant's inability to pay his rent was the reason for this type of refusal; but refusing to renew a lease or evicting small farmers also allowed landlords to modernise their estate, and to turn their lands into pasturage. If they did so, the whole family, which depended on the culture of these lands, was plunged into utter distress, and this explains the emergence of the National Land League in 1879, created to protect the peasants from evictions. In Ireland, the nineteenth century was marked by the struggle for land, as Irish tenants started to question the authority and right of their landlords to own land which was cultivated and inhabited by others (Curtis, 2011, pp. 81-129). Irish politicians like Charles Stewart Parnell, Michael Davitt and John Dillon enticed peasants to resist evictions, but at the time when Nicol painted The Lease Refused, resistance was not yet well organised. In this picture, a dignified Irish farmer is standing on the left, while the estate agent, sitting at his desk, has just refused to renew the lease. In the right hand corner, a clerk is rummaging through a box. There are several versions of this painting, and one of the earliest was shown at the Royal Academy in 1863, and then at the Royal Scottish Academy in 1864. Nicol painted another in 1868, which was exhibited in Glasgow in the same year, and the composition was reproduced in the form of engravings in 1868 and 1870 , so the work was well-known by the British public. When it was exhibited again at the London International Exhibition in 1871, an English journalist commented:

Many works, it will be noticed, are here which have been exhibited before, but their quality demands that at least they should be named. Their presence is undoubtedly welcome, for on each occasion of their exhibition they are seen with renewed interest. Among these, besides those already pointed out, are [...] Renewal of the Lease Refused, E. Nicol, ARA. (The Art Fournal, 1 August 1871, p. 201)

The renowned work echoed another painting by Nicol, entitled Signing the New Lease and dated 1868, which showed the same interior as in The Lease Refused, with the same agent and clerk, but with them standing on either side of another peasant about to sign his new lease. ${ }^{16}$ Both works

16. The oil on canvas is part of the collection of the New Walk Museum \& Art Gallery, Leicester, and can be seen at: <www.bbc.co.uk/arts/yourpaintings/paintings/signing-the-new-lease-80976>. 
illustrate the two potential outcomes of a lease termination for Irish peasants, thus showing Nicol's awareness of the tenants' dependency on their landlords.

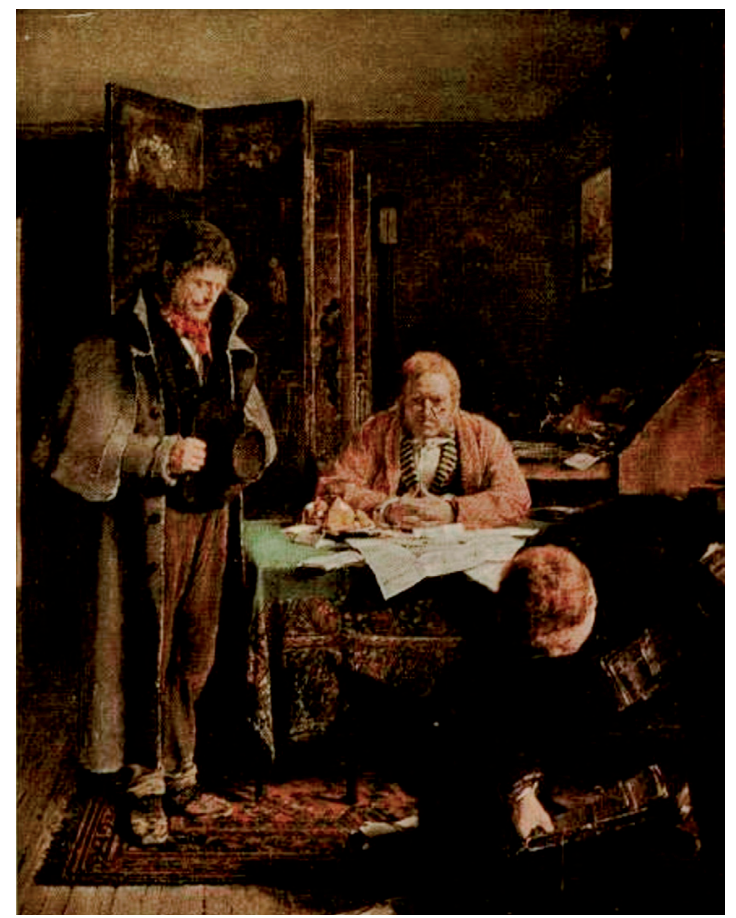

The Lease Refused, coloured illustration published in Anna Maria Carter Hall, Tales of Irish Life and Character, London \& Edinburgh, TN Foulis, 1909, p. 136.

(c) Amélie Dochy, all rights reserved.

The picture was appreciated by British art critics, despite the misery conveyed by the subject matter, for its realism, which reflected a situation faced by many Irish tenants. When contemporary viewers discovered the painting, they were well aware of its realism, as numerous newspapers reported the troubles caused in Ireland by the land question. In this context, a Scottish reviewer provided the following interpretation of the painting:

Of course, one guesses how it will end. The poor fellow will be turned out; and some fine night when the agent is riding home from the market town with a comfortable quantity of potheen in him a shot will sputter from behind the hedge, and an Irish nobleman, mostly resident in London, will have to look 
out for another agent to manage his affairs, and in the market town some six months hence there will be a poor devil to hang who will not be persuadedlet the priest talk over so much - that he is a great sinner on account of the deed which dooms him. (The Caledonian Mercury, 18 February 1864)

Interestingly, Nicol's scene could not be interpreted in this way today, since his protagonist does not express any sign of violence. His posture, and the embarrassed manner in which he holds his hat, would rather be understood as signs of resignation nowadays. In spite of this apparent stillness, for the contemporary viewers, the scene was full of an underlying violence, as their interpretation depended on the stories that they could read in their daily or weekly newspapers, which gave numerous examples of murdered agents and rebellions, a phenomenon which became particularly notorious with the rise of the Fenians (in 1867). Although the Land Leaguers did not encourage tenants to resort to physical violence, the Fenians did, so that both movements were usually associated with brutality by British journalists. Many debates, in parliament and in the press, tried to identify the causes of such violent behaviour, and in the 1860s, newspapers laid the blame on absentee landlords, who were seen as responsible for the mismanagement of their estates, and the predicaments of Irish peasants. This belief led art critics to analyse in a negative light the characters that Nicol depicted in the service of the landlord: the agent was noticeable for his "dogged obstinacy", which forbade "any further appeal" (The Bradford Observer, 26 July 1873, p. 8), and his clerk was marked by an "air of unconcern" (Trewman's Exeter Flying Post or Plymouth and Cornish Advertiser, 13 July 1870). The Art fournal, which provided a detailed commentary of the 1863 painting, along with a fullpage engraving reproducing it, was warier in its explanations, and the journalist insisted on his refusal to take sides:

The landlord may be a tyrant in his own domains, or he may be seeking only to maintain his lawful rights; the tenant may be oppressed by the exactions of the lord of the soil, or an idler who allows briars and thistles to grow where corn should spring up or the potato cover the ground with its purple blossoms. We, in our critical capacity, are not called upon to express any opinion upon this debatable question, nor does the closest examination of Mr. Nicol's picture throw the least light upon it, so as to lead to a just conclusion about the rights or wrongs of either party. (Dafforne, 1 July 1870, p. 200)

With such an introduction, the reader is surprised to find a contradictory statement in the next paragraph, which highlights the decency, and therefore apparent honesty of the tenant, a positive figure contrasted with the agent, whose hard and inflexible face are noted by the journalist. James Dafforne even identifies the agent as a man who is perfectly satis- 
fied with the performance of such a distasteful function. ${ }^{17}$ Although the art critic refuses to admit it, his own interpretation of the painting leads to the recognition of the tenant's sufferings, and of the injustice generated by the decision of the landlord, whose will is communicated to the peasant by the determined estate agent. The pictorial denunciation of the injustices occurring on Irish soil that is conveyed by this artwork confirms Nicol's empathy towards Irish tenants, a feeling which might be explained by his own experience - as he lived in Ireland at the time of the Great Famine (1847-1852) - , but also by his Scottish sensitivity.

The distress of these Irish farmers is redolent of Scottish history. In Scotland, tenants faced the same difficulties in renewing their lease or paying their rent, a reality which had been depicted by Wilkie in The Rent Day (1807) or Distraining for Rent (1815). From the first painting to the next, Wilkie's criticism of the landlord-tenant relationship was made less subtle, as The Rent Day still includes many comic details: the dutiful tenants, who have paid their rent, are rewarded by being offered a good lunch in the background on the right, while in the foreground, one peasant is bent forward, with a wide-open mouth, as if he were violently coughing, and another is absent-mindedly pressing his walking-stick against his upper lip. In contrast, Distraining for Rent ${ }^{18}$ does not represent any humorous incident. All the characters play a role in enhancing the tragedy of this situation, and in foreshadowing the impending dispossession. A group of women and children on the left are grieving, the farmer is leaning on the table and rubbing his forehead in despair, unable to pay attention to the child on his right, whereas the cause of their despair, the bailiff, is seen standing defiantly on the right, holding in his hand a white letter which may be an eviction note, while his assistant, sitting on the bed, seems to be recording all the family's belongings, so that the enforcer with a red hat may perform his job. The gestures, facial expressions and postures of these characters relate the tragic story unfolding before our eyes, a device which did not fail to touch contemporary onlookers. Although David Wilkie was known for his unionism, the British Institution, which owned the painting at that time, did not exhibit the canvas for several years, for

17. "The man is decent-looking enough, and probably has done his best to turn his holding to good account: he desires to have his lease renewed, but is met by refusal; it is evident from the stern and unyielding countenance of the agent, that no argument, nor appeal to pity, nor threats - if such were resorted to - would move him from his determination: there is something vastly expressive of inflexibility in that hard face, with its compressed lips and contracted eyebrows, and even in the clasped hands with the upturned thumbs: the man is a study of an inexorable nature. It is just possible, however, that in the interests of his employer, he is only performing his duty, though it seems to be much in accordance with his own feelings." (Dafforne, 1 July 1870, p. 200)

18. Wilkie's oil on panel belongs to the National Gallery of Scotland and is visible on their website: <www.nationalgalleries.org/collection/artists-a-z/W/6004/artist_name/Sir David Wilkie/record_ $\mathrm{id} / 2512>$. 
fear that the public might be offended by its underlying questioning of authority. Edward Pinnington wrote that British prejudices at the time went against the work:

[Distraining for Rent] was sent to the Exhibition of the British Institution, where the directors bought it for six hundred guineas. The after-history of the picture makes striking revelation of the hot prejudices of the time. Haydon tells that after purchasing it the directors had so many misgivings concerning its subject, that they hid it for years in the lumber-room. They did not dare exhibit it, and Haydon explains that the whole tone and temper of society were against reflections upon established authority. (Pinnington, 1900, p. 101)

Wilkie's picture struck a chord with the Victorians because the bailiff and his assistant embody the laws on insolvency which had been passed in 1813, but which only applied to England - since legal requirements were different in Scotland-, so that the painting was clearly made to be understood by an English public (Morrison, 2003, p. 28). In his depictions of Irish troubles, Erskine Nicol used similar techniques, but he was not confronted with a comparable reception, which may be accounted for by the growing awareness of the peasants' predicament in the 1850s. Indeed, Nicol's depictions of the troublesome relationships between landlords and tenants were presented to the British public forty years after Wilkie's, when the Victorians had already been touched by the poignant reports on the Irish Famine (1847-1852) which had been published with upsetting engravings in The Illustrated London News, one of the most popular newspapers of the time, whose circulation reached 200,000 copies per week in 1855 (Hibbert, 1975, pp. 13-4). This is probably why Nicol's picture was well accepted by its public; it only confirmed what they already knew about the so-called "Irish Question". As the painting corroborated the general opinion according to which immoral landlords were responsible for the grievances of the Irish, its success was not compromised by the fear of artistic institutions to go against the grain in terms of politics, as had been the case with Wilkie's picture.

It is true that when Wilkie showed his Distraining for Rent, the work was evocative of the sorrowful and sometimes violent episode of the Highland clearances, which took place between 1780 and 1855. This draws a parallel with scenes of evictions in Ireland, which were also particularly violent between the 1840 s and the first decade of the twentieth century, as the militia in charge of these expulsions often dragged the tenants out of their cottage by force of arms, and then destroyed their farms (Curtis, 2011). The fact that Scottish tenants were experiencing similar difficulties, including poverty, evictions and emigration, must have made Nicol more sensitive to the hardships faced by Irish peasants. 
A shared experience accounts for comparable artistic productions, and in the nineteenth century, Scotland and Ireland had more than their Celtic identity in common. Both nations were on the fringes of the United Kingdom, and they both tried to define a national identity for themselves, in order to preserve their cultural values from assimilation with those of England. ${ }^{19}$ It is thus unsurprising that, when the Scottish artist Erskine Nicol depicted Ireland and the Irish, the themes and style of the Scottish school should appear so transparently in his works. Consequently, his name can be added to the list of the painters belonging to this movement. An interpictorial analysis, focusing on "the conversation among the images" from different artists (Hahn, 1999, p. 110), allows viewers to distinguish the elements that Nicol borrowed from other painters, which offers a better understanding of his artistic affiliations. This is how some paintings by David Wilkie can be seen through the artworks of Nicol. Being born a Scot, and having been educated in a Scottish academy, Nicol was unsurprisingly influenced by the Scottish school. The invisibility of "Highlandism", even in his Scottish representations, does not mean that he was not aware of Scottish history, since some of his paintings showing the helplessness of Irish peasants are redolent of the Highland clearances. Thus, the originality of Nicol was to adapt a typically Scottish style to the depiction of Irish life, a subject matter for which there was less competition on the British art market.

\section{Bibliography}

\section{Articles}

Amblard Marion, "Du Rebelle au héros, Les Highlanders vus par les portraitistes des Lowlands entre 1680 et 1827", Études écossaises, no. 11, 2008, pp. 193-205. The article is also available online: <http://etudes ecossaises.revues.org/index87.html\#authors>.

—, "Les Tableaux d'Horatio McCulloch et des paysagistes écossais du XIx siècle", Études écossaises, no. 12, 2009, pp. 145-59. The article is also available online: <http://etudesecossaises.revues.org/index200. html\#text>.

HaHn Cynthia, "Interpictoriality in the Limoges Chasses of Stephen, Martial, and Valerie", in Colum Hourihane (ed.), Image and Belief:

19. The need to define Scottish identity was all the more problematic as the Lowlands were anglicized, contrary to the Highlands. It was thus difficult to provide a unified definition of the nation which would reflect this diversity. 
Studies in Celebration of the Eightieth Anniversary of the Index of Christian Art, Princeton, Princeton University Press, 1999, pp. 109-24.

\section{Books}

CurTis Lewis Perry, The Depiction of Eviction in Ireland 1845-1910, Dublin, University College Dublin Press, 2011.

Graves Algernon, The Royal Academy of Arts, a Complete Dictionary of Contributors and their Work from its Foundation in 1769 to 1904, London, H. Graves \& Co, 1905.

Hall Anna Maria, Tales of Irish Life and Character with Pictures by Erskine Nicol, London \& Edinburgh, TN Foulis, 1909.

Harvey William, Scottish Life and Character in Anecdote and Story, Illustrations by Erskine Nicol and Others, Stirling, Eneas Mackay, Philadelphia, J. B. Lippincott Company, 1911.

Hibbert Christopher, The Illustrated London News' Social History of Victorian Britain, London, Angus \& Robertson, 1975.

IRwIN David and Francina, Scottish Painters at Home and Abroad, 17001900, London, Faber \& Faber, 1975.

McKay William D., The Scottish School of Painting, London, Duckwroth \& Co., New York, Charles Scribner's Sons, 1906.

Meynell Wilfrid, Some Modern Artists and their Works, London, Cassell, 1883, pp. 148-52.

Morrison John, Painting the Nation, Identity and Nationalism in Scottish Painting, 1800-1920, Edinburgh, Edinburgh University Press, 2003.

Pinnington Edward, Sir David Wilkie and the Scots School of Painters (1846-), Edinburgh, Oliphant, London, Anderson \& Ferrier, 1900.

Rinder Franck, The Royal Scottish Academy: 1826-1916, Glasgow, James Maclehose \& Sons, 1917.

Thomas Julia, Pictorial Victorians: the Inscription of Values in Word and Image, Athens (Ohio), Ohio University Press, 2004.

VInDEx Veri, Thoughts on Art and Notes on the Exhibition of the Royal Scottish Academy of 1868, Edinburgh, Alexander Hislop \& Co., London, Simpkin, Marshall \& Co., 1868.

\section{Artworks}

BeLl Charles Robert, The Renewal of the Lease Refused, black and white engraving, published in 1868, in London, after Erskine Nicol, The Renewal of the Lease Refused, 1868.

- The Renewal of the Lease Refused, black and white engraving, published in 1870, in The Art Journal, London, p. 200, after Erskine Nicol, The Renewal of the Lease Refused, 1868. 
Chalmers George-Paul, The Legend, oil on canvas, 103 x 154 cm, 186478, National Gallery of Scotland.

—, Reading by the Fireside, oil on canvas, 26 x $35 \mathrm{~cm}$, undated, The Fleming Wyfold Art Foundation.

FAED Thomas, Faults on Both Sides, oil on canvas, 67 x 55 cm, 1861, Tate Gallery.

Gavin Robert, Fooling Around, oil on canvas, 63 x 75 cm, undated, private collection.

MaCulloch Horatio, Glencoe, oil on canvas, 110 x 182 cm, 1864, Kelvingrove Art Gallery and Museum.

Nicol Erskine, An Ejected Family, oil on canvas, 50 x 82 cm, 1853, National Gallery of Ireland.

—, Grandmother and Grandson, oil on canvas, 60.5 x 50.5 cm, c. 1870, private collection.

_- The Lease Refused, oil on panel, 56 x $43 \mathrm{~cm}, 1863$, private collection.

-, The Lease Refused, coloured illustration, published in Anna Maria Carter Hall, Tales of Irish Life and Character, London \& Edinburgh, TN Foulis, 1909, p. 136.

- Never Tell a Lie Duncan, coloured illustration, published in William Harvey, Scottish Life and Character in Anecdote and Story, Illustrations by Erskine Nicol and Others, Stirling, Eneas Mackay, Philadelphia, J. B. Lippincott Company, 1911, p. 440.

-, Renewal of the Lease Refused, oil on canvas, 94 x $71 \mathrm{~cm}, 1868$, private collection.

—, The Ryans and Dwyers, Calumniated Men, oil on canvas, 33 x $43.5 \mathrm{~cm}$, 1856, private collection.

_, Signing the New Lease, oil on canvas, 122 x 93.5 cm, 1868, New Walk Museum and Art Gallery.

RAEBURn Henry, Alastair Ranaldson Macdonell of Glengarry, oil on canvas, $242 \times 151 \mathrm{~cm}, 1812$, National Galleries of Scotland.

—, Francis MacNab, oil on canvas, 241 x 152 cm, c. 1813, Kelvingrove Art Gallery and Museum.

Raimbach Abraham, Village Politicians, black and white engraving, published in 1813, after David Wilkie, Village Politicians, 1806, private collection, Scone Palace.

Simmons William Henry, Always Tell the Truth, black and white engraving, published in 1876, in London and Washington DC, after Erskine Nicol, Grandmother and Grandson, c. 1870.

WiLkIE David, Distraining for Rent, oil on panel, 81 x 123 cm, 1815, National Galleries of Scotland.

_- The Rent Day, oil on wood, 63 x 88 cm, 1807, private collection. 
—, Pitlessie Fair, oil on canvas, 61 x 110 cm, 1804, National Galleries of Scotland.

—, The Blind Fiddler, oil on mahogany, 58 x $80 \mathrm{~cm}, 1806$, Tate Gallery.

- Portrait of George IV, oil on canvas, 279 x 179 cm, 1829, Royal Collection, UK.

\section{Nineteenth Century Newspapers}

Signed articles

DAfForne James, "Renewal of the Lease Refused", The Art Fournal, London, 1 July 1870, p. 200.

—, "British Artists, their Styles and Characters: Erskine Nicol, R.S.A, A.R.A”, The Art fournal, London, 1 March 1870, pp. 65-7.

Anonymous articles

The Art fournal, London, 1 July 1871, p. 180.

The Art Fournal, London, 1 August 1871, p. 201.

The Bradford Observer, Bradford (England), 26 July 1873, p. 8.

The Caledonian Mercury, Edinburgh, 4 March 1858.

The Caledonian Mercury, Edinburgh, 18 February 1864.

Trewman's Exeter Flying Post or Plymouth and Cornish Advertiser, Exeter (England), 13 July 1870. 